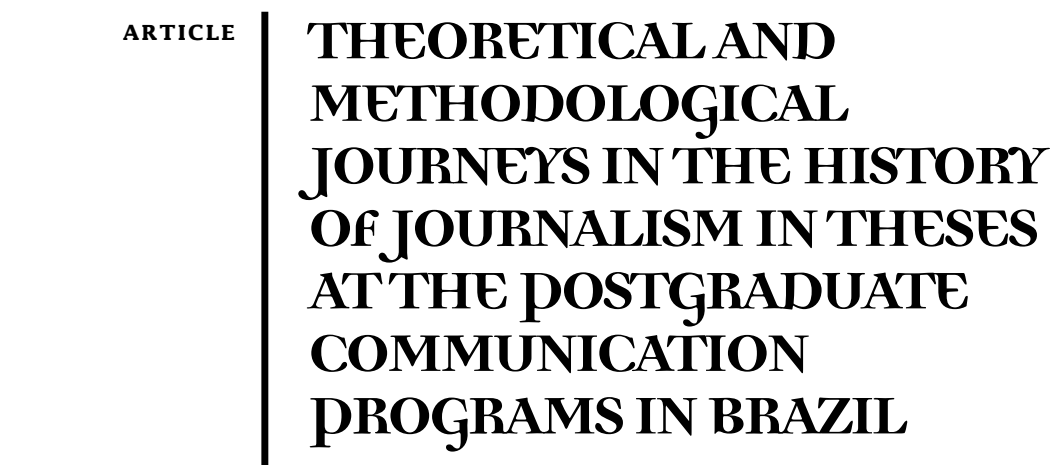

Copyright (c) 2010 SBPJor / Sociedade Brasileira de Pesquisa em Jornalismo

FELIPE SIMÃO PONTES

Federal University of Santa Catarina

GISLENE SILVA

Federal University of Santa Catarina

ABSTRACT Research on theses in Brazilian postgraduate Communication programs that deal with the history of journalism. The study is based on the particular methodological strategies used in these works that recognise Journalism as a legitimate area of study and its relationship to History. As such, it places its methodological survey at the crossroads of the conceptual-theoretical perspectives of Journalism and History, aiming, as its central objective, to reflect on the subject of study of Journalism ${ }^{1}$.

Key-words: history of journalism, methodology, postgraduate Communication studies.

\title{
INTRODUCTION
}

The field of journalistic reasearch has become stronger in the last couple of years in Brazilian postgraduate communication programs. In spite of this fact, the consolidation of its theory, methodology and epistemological thinking, in relation to the most appropriate contribution to the investigation of the journalistic phenomemon -one among the many in the communications area- has not been very fruitful. One can observe that at the same time in which Brazilian academic reasearch in the area gathers momentum and visibility, the demand for a more accurate study of its adopted methodologies is urgently needed.

Brazilian academic research in communication must take into consideration dissertations and theses produced in the area of the history of journalism; as it happens in other countries, observing the subject of journalism from a historical perspective has been one of the 
most traditional approaches to reasearch in journalism (Zelizer 2004, p. 81 and Wilkerson 1968, p. 13). However, very much like the other approaches to the study of journalism, the historical approach also proves problematic in its methodological strategies. It is in this context that this research aims at tracing the particulars of the methodological strategies adopted by the theses produced in postgraduate programs on the history of journalism from 1972 to 2006. Studying the research on the history of journalism initially provides us with the necessary critical distance for a "reasearch of a research". As Maldonado (2003, p. 205) says of communication, the methodological/theoretical and gnostical problems of journalism "[...] demand a deepening of the historical perspectives used in struturing its reasearch". Reviewing these perspectives, as is the case of this research, calls for the necessity of showing how different researchers in the history of journalism organize their methods and concepts in such a way that it becomes possible to describe how journalism is regarded as an subject for research.

In order to deal with problems at the crossroads of journalism and history, this study has reaffirmed many of the questions brought about by a confrontation of theories and methods. In our exercise we have sought concepts and methodologies that enrich a comparison between history and journalism and that promote a concept of the history of journalism, thus establishing new horizons for the theory of journalism. This disposition has enabled us, as a broader meditation, to map out if and how researchers use concepts from different academic fields, realizing how history, journalism and the history of journalism are understood under these circunstances.

This research has also noticed how the theoretical-methodological procedures influence the path each researcher has taken in order to weave an association between the empirical observation of its subject and the theoretical reference. The requirements of a research of this nature have also demanded a methodological procedure that enabled a characterization of the methodology of the research works scrutinized, their backbone - as Santaela (1999) affirms - , in order to later confront it with theoretical questions. What is understood here as the methodological strategy adopted is the approach to the subject for study, the questioning, proposal of hypotheses, alignment of concepts and methodological procedures for selection and analysis.

Our ultimate goal here is not only to contribute to the systematization of options and methodological protocols in these research works, but also to collaborate, on a second analysis, in the consolidation of the 
theoretical and epistemological basis of journalism, the reason for our methods and methodologies. Ours is a critical exercise, since the approach it assumes in relation to its subject for study, its hypothesis proposed, its theoretical and methodological options will focus on the concepts of journalism and journalism history used by these studies. Are the interests of these research works centered on journalism? Or are their paths gradually transforming them into questioning other areas of study? We understand that the way these research works conceive of journalism results in the formulation of their methodological strategies. The review of a significant Brazilian academic body of research in the history of journalism helps to map out just how journalism has been understood and to observe the potential of its relevant theoretical field.

\section{Comments on methodology}

Our first research task was to gather all theses and dissertations in 30 programs in the area. Since ten programs did not have theses or dissertations until 2006 (the end of the period considered), the empirical subject of this research has come down to 20 programs $^{2}$. In this way, it has become possible to select which research works deal with journalism and which deal with the history of journalism. Our starting point already reveals the first obstacle. The country lacks any form of systematization for academic research in postgraduate studies in communication. The most advanced study of this kind has been carried out by Ida Stumpf (three volumes- the first two written with Sergio Capparelli and the last one with Rafael Rocha and Samile Vanz), and presents all research carried out between 1992 and 2002 by all the postgraduate programs in the country. However, our interest in this research has been to collect the entire research production of the postgraduate courses in communication until 2006, which has required us to go back to the first theses and dissertations of the early 1970s. In order to bridge this gap, our research has focused on the databases of postgraduate programs. Our first conclusion is that many postgraduate programs and libraries lack a systematized recording of theses and dissertations.

Our solution then was to focus on the databases of Capes (Coordinating Body for Improvement of University-level Personnel). This option encountered two additional difficulties. First, Capes databases are not organized according to each postgraduate program. In practice, this meant that in order for us to recognize which theses and dissertations were on communication, it became necessary for us to open each and every abstract from a given university from a given year. The second 
difficulty arose from the fact that Capes only keeps records of the theses and dissertations starting in 1987. Five universities had postgraduate programs beginning before that: USP, UMESP, PUC-SP, UFRJ and UnB. Of these five, only two, USP and UMESP, keep records of their production online. Professor Richard Romancini, who studies such problems (2007), kindly made available a copy of all theses at UFRJ from 1972 to 1986 organized by Silva and Cavalcanti (1989) and of dissertations at UnB from 1977 to 1982 (PORTO, 1982). In the specific case of UnB dissertations from 1983 to 1986, the gap could only be filled at the beginning of October of 2008 when the program made its records available online. However, the program in Communications and Semiotics at PUC-SP does not have any record of its production. Faced with this, our proposal was to cross the number of theses and dissertations of this program presented by G.Silva (1989) until 1988 with data collected from the library of the institution and from unofficial research carried out by Romancini on the "Lattes" curriculum of professors.

It is worth pointing out that data prior to 1987, as well as information regarding theses and dissertations that the programs do not send to Capes, make it difficult to calculate the exact amount of works. In spite of this, the data presented in this research can be thought of as being as close as possible to the real numbers, since in many cases the data has been crossed with the databases of the programs, Capes and the research carried out by Ida Stumpf.

Our next task was to sift through the abstracts which dealt with communication and those which dealt with journalism. We took into consideration terms used in the title, abstract and key words. The terms analyzed were: journalism, newspaper, journalist, press, news, report, reporter, brand name of the journalistic enterprise, journalistic text, TV newscast, radiojournalism, press relations, theoretical/ practical personality of journalism and magazines (excluding those of an academic nature).

Once the initial step of selecting the material was completed, we embarked on the qualitative reading of the abstracts in journalism trying to establish which of these could be characterized as historical studies. To a certain degree, one could notice that each research had a historical dimension. However, only those research works that treat the history of journalism as central to their approaches and emphatically express this in their abstracts, title or keywords have been taken into consideration.

After mapping out the thesis and dissertation abstracts in communication, selecting those concerning journalism and studying 
those involving the history of journalism, we observed the distribution of the production in journalism and in the history of journalism in these postgraduate programs.

\begin{tabular}{|c|c|c|c|c|c|c|}
\hline \multicolumn{7}{|c|}{$\begin{array}{r}\text { Chart 1: THESES in communication, journ } \\
\text { until } 2006\end{array}$} \\
\hline & Communication & \multicolumn{2}{|c|}{ Journalism } & \multicolumn{3}{|c|}{ History of Journalism } \\
\hline PUC-RS & 69 & 19 & $27.5 \%$ & 02 & $2.9 \%$ & $10.5 \%$ \\
\hline PUC-SP ${ }^{3}$ & 436 & 46 & $10.5 \%$ & 20 & $4.6 \%$ & $43.4 \%$ \\
\hline UFBA & 41 & 12 & $29.3 \%$ & 04 & $9.8 \%$ & $33.3 \%$ \\
\hline UFF & 02 & 00 & - & 00 & - & - \\
\hline UFRGS & 06 & 03 & $50 \%$ & 01 & $16.7 \%$ & $33.3 \%$ \\
\hline UFRJ & 297 & 62 & $20.9 \%$ & 15 & $5.1 \%$ & $24.2 \%$ \\
\hline UMESP & 61 & 27 & $44.3 \%$ & 09 & $14.8 \%$ & $33.3 \%$ \\
\hline UNICAMP & 30 & 03 & $10 \%$ & 01 & $3.3 \%$ & $33.3 \%$ \\
\hline UNISINOS & 46 & 12 & $26.1 \%$ & 00 & - & - \\
\hline USP & 751 & 103 & $13.7 \%$ & 30 & $4 \%$ & $29.1 \%$ \\
\hline TOTAL & 1437 & 287 & $20 \%$ & 82 & $5.7 \%$ & $28.6 \%$ \\
\hline
\end{tabular}

\begin{tabular}{|c|c|c|c|c|c|c|c|}
\hline \multicolumn{8}{|c|}{ Chart 2: DISSERTATIONS in comunication, journalism and history of journalism } \\
\hline & Communeation & & alism & His: & $y$ of Jour & alism & \\
\hline $\mathrm{FCSCl}$ & 46 & 14 & $30.4 \%$ & 03 & $6.3 \%$ & $21.4 \%$ & \\
\hline PUC-RIO & 22 & 08 & $36.4 \%$ & 04 & $18.2 \%$ & $50 \%$ & \\
\hline PUC-RS & 192 & 53 & $27,6 \%$ & 10 & $5.2 \%$ & $18.8 \%$ & \\
\hline PUC-SP & 441 & 34 & $7.7 \%$ & 06 & $1.4 \%$ & $17.6 \%$ & \\
\hline UERJ & 27 & 12 & $44,4 \%$ & 03 & $11.1 \%$ & $25 \%$ & \\
\hline UFBA & 136 & 47 & $34,6 \%$ & 06 & $4.4 \%$ & $12.8 \%$ & \\
\hline UFF & 101 & 31 & $30.7 \%$ & 12 & $11.9 \%$ & $38.7 \%$ & \\
\hline UFMG & 75 & 25 & $33,3 \%$ & 03 & $4 \%$ & $12 \%$ & \\
\hline UFPE & 72 & 23 & $31,9 \%$ & 02 & $2.8 \%$ & $8.7 \%$ & \\
\hline UFRGS & 94 & 36 & $38,3 \%$ & 04 & $4.3 \%$ & $11.1 \%$ & \\
\hline UFR & 833 & 171 & $20,5 \%$ & 35 & $4.2 \%$ & $20.5 \%$ & \\
\hline UMESP & 463 & 148 & $32 \%$ & 49 & $10.6 \%$ & $33.1 \%$ & \\
\hline UnB & 217 & 73 & $33,6 \%$ & 15 & $6.9 \%$ & $20.5 \%$ & \\
\hline UNESP & 88 & 37 & $42 \%$ & 03 & $3.4 \%$ & $8.1 \%$ & \\
\hline UNICAMP & 203 & 17 & $8.4 \%$ & 05 & $2.5 \%$ & $29.4 \%$ & \\
\hline UNIMAR & 48 & 19 & $39,6 \%$ & 03 & $6.3 \%$ & $15.8 \%$ & \\
\hline UNIP & 127 & 20 & $15,7 \%$ & 04 & $3.1 \%$ & $20 \%$ & \\
\hline UNISINOS & 123 & 42 & $34,1 \%$ & 06 & $4.9 \%$ & $14.3 \%$ & \\
\hline USP & 1460 & 233 & $16 \%$ & 66 & $4.5 \%$ & $28.3 \%$ & \\
\hline UTPrnalis & 79 & 15 & $19 \%$ & 04 & $5.1 \%$ & $26.7 \%$ & \\
\hline
\end{tabular}

As charts 1 and 2 reveal, the number of academic research works considered to be in the area of the history of journalism is significantly higher among the theses than the dissertations of communication and journalism. There are 82 theses and more than 200 dissertations, an amount which proved the individual study of the theoretical/ 
methodological strategies of the proposed period to be untenable. Thus, given the greater methodological rigor present in theses (and also because of the presence of a hypothesis) we have opted for the study of the concepts of journalism, history and history of journalism in the theses on the history of journalism. That, however, does not mean data on dissertations and certain strategies used by them have not been verified (our aim is to continue researching until the mapping is complete). Attention has been given to these 82 theses as a feasible focus and as a reading strategy. However, 82 is still a very high number of works and if on the one hand, until now there has been no attempt at sifting through the number of works that pay special attention to journalism, on the other hand, a second filter became necessary. Thus, five different categories were devised in order to deal and categorize the position of journalism in historical research works:

(1) Journalism - as a professional and enterpreneurial activity regarded as an historical document with autheticating value since it documents events that took place at a certain time, records the behavior of population, their hobbies and leisure preferences or even the performance of a public service. In these particular cases, journalism helps the historian present and contextualize an era or even offer alternate perspectives of events. In these instances, the interest of the researcher is not in journalism in itself, but the facts brought to light. Journalism becomes a source that the researcher uses to study other subjects.

(2) Journalism is reviewed with the specific purpose of restoring the professional, intelectual and enterpreneurial memory of the area. It is made up of biographies (of journalists, newspaper owners, researchers etc.), stories of journalistic enterprises, alternative newpapers, from unions, political parties, governments, catalogs in general that justify it insofar as it preserves pioneer works on particular matters, demonstrating the tranformation of technique and content in these publications. When informed by the "positive school" of thought (REIS, 2006), this way of addressing journalism often serves merely to solidify the memory of its founders, the text is written as an hommage and the interest is political/ institutional rather than conceptual. This situation is repeated in research that aims at retrieving the chronological journey of a given newspaper, transforming their founders and first directors into heroes. Journalism appears as the subbject for study but the real focus is on the company/ director/historicized researcher.

(3) In other research works, it is the work of the journalist which 
becomes the focus of the study. Under scrutiny then is the process of newsmaking, the institutionalization of routines, the transformation of writing styles, deontology and professional discourse. In order to achieve that, the researcher becomes interested in the particulars of journalistic practice in different eras, which strategies are used to cover an event, what genres are born to deal with a series of facts, how subjects appear in the text, how journalistic companies are organized, what forms of gatekeeping are devised, how reporters work, how public reception is viewed. Journalism is viewed in context, but alienated from it. The researcher considers journalism his subject for study, concerned with the transformations that take place inside newspaper companies and their products, the organization and journalistic practices as a way of answering why journalism works the way it does.

(4) Journalism can also be studied as an actor that directly interferes in reality. In this particular case, the researcher aims at recognizing how the role performed by this activity influences and modifies the social context of a given period helping constitute social imagination, political trends, and actively participating in the process of public opinion formation as well as in positions in other social fields. Journalism is considered from the viewpoint of its complexity, the amplitude of its concept that involves not only the various journalistic activities but also the public exercising of journalistic knowledge and alliances that different social actors perform to communicate their interests as journalistic information. The recognition of journalism's role and its influence on reality depends on the perspective taken by studies of journalism, and the concepts relevant to this field of knowledge.

(5) In addition, journalism can be studied historically as a place of theoretical and epistemological questioning. The researcher turns to historical practice in order to clarify concepts and to describe the emergence of theories according to the context in which a certain activity is inserted. Research works indicate a theoretical positioning which favors the constitution of this area of knowledge and tries to create and use concepts that are relevant to the field for the study of journalism as a phenomenon. Thus one tries to establish how professional, social, cultural and theoretical practices throughout history make reference to an epistemological and theoretical exercise that seeks to constitute concepts capable of contributing to an understanding of the journalistic field.

There is one last category in which to place those works that do not fit into the above categories and which essentially deal with the way history is understood by the professional journalist with regard to 
certain historical events.

It is interesting to note in chart 3 how high the number is of theses that deal with journalism as a means to research the interests of other disciplines (23 cases) and rather how scant are research works on the history of journalism that favor the constitution of concepts for journalism (initially only four research works).

\begin{tabular}{|c|c|c|c|c|c|c|c|}
\hline \multicolumn{8}{|c|}{ Chart 3: Distribution of theses among categories } \\
\hline & $\begin{array}{l}\text { (1) } \\
\text { As } \\
\text { documents }\end{array}$ & $\begin{array}{l}\text { (2) } \\
\text { Alagrsplaies / } \\
\text { Newspapen } \\
\text { histaries }\end{array}$ & $\begin{array}{l}\text { (3) } \\
\text { Professional } \\
\text { peactice } \\
\text { Ppodustice }\end{array}$ & $\begin{array}{l}\text { (4) } \\
\text { Contest } \\
\text { interfference }\end{array}$ & $\begin{array}{l}\text { (5) } \\
\text { Conneptual } \\
\text { and } \\
\text { theorstical } \\
\text { eactioca }\end{array}$ & Other & Total \\
\hline PUC-RS & ot & - & 01 & - & $\cdot$ & - & 02 \\
\hline PUC-SP & 12 & 04 & 04 & - & . & & 20 \\
\hline UFBA & 01 & 01 & 01 & $\cdot$ & 01 & - & 04 \\
\hline UFRGS & 01 & 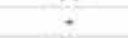 & 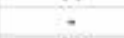 & - & $\cdot$ & - & 01 \\
\hline UFRJ & 03 & 01 & 04 & os & - & 02 & 15 \\
\hline UMESP & . & 07 & 02 & . & - & . & 09 \\
\hline $\begin{array}{l}\text { UNICA } \\
\text { MP }\end{array}$ & 01 & $\cdot$ & 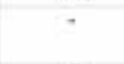 & * & - & - & 01 \\
\hline USP & 06 & 06 & 04 & 10 & 03 & 01 & 30 \\
\hline TOTAL & 25 & 19 & 16 & 15 & 04 & 03 & 82 \\
\hline
\end{tabular}

From the five categories, we selected theses that view journalism in their abstracts and titles according to categories 3 (16 theses), 4 (15 theses) and 5 (4 theses). For the proposed exercise, we understand that these categories seem more strategic in mapping out concepts and methods. Our selection is justified insofar as these research works do not favor memory and do not view journalism as a means of authenticating the interests of another area. From this perspective, we consider it necessary to advance further in positions that have already been awarded to journalism such as its recognition as an historical document and also of descriptive studies that try to recover memory. This, however, does not mean that the unselected theses are not pertinent, but that methodologically, the potential is greater in the selected corpus. Thus, from their abstracts, titles and keywords we have selected 31 theses to build our corpus - acknowledging that the other 4 theses were not available during our investigation process. Each thesis from this entire empirical material has been cataloged in sample cards containing their abstract, subject for study, problem, hypothesis, theoretical references, methodological procedures and reference authors. 
From many crossreadings and crossreferencing we obtained information that reveals the theoretical-methodological strategies contained in these research works on the history of journalism and also information that reveals how journalism is understood in these works.

\section{Final remarks}

The emphasis on the theoretical-methodological strategies of these research works has the purpose of not only revealing trends that were hinted at in their abstracts but also of studying the ways in which the concept of journalism proposed by the researchers determines the very subject of research, its questioning, the formulation of hypotheses and especially the link of the research work's subject for study to the study of journalism as a legitimate area of knowledge.

In a very succint form, it has been possible for us to observe how, in the verifying of hypotheses and questioning of the theses that, in many cases, the criteria used does not become integrated with concepts and theories that can deal with journalism's complexities as a subject for study. Many theses reduce the concept of journalism to its subject for study, all the time treating partial aspects as general characteristics of the entire field. In many other cases, particularly in those that derive their conceptual approach from other areas that see journalism according to their own lenses, journalism is not seen from the perspective of its theoretical premisses. Thus a position is made available for another field of knowledge to criticize journalism, putting aside any theoretical pretenses journalism as a legitimate field of study might have expressed.

In analyzing the methodological and theoretical strategies centrally placed by the theses as research questions, one notices the presence of concepts and authors from other areas of knowledge,. in particular sociology and linguistics. What becomes clear in the dialogue between methodological approaches and theorical-methodological choices, in this exercise of understanding journalism, is that for the most part, the theses on the history of journalism produced in Brazil do not take intoconsideration the Theory of Journalism. The objective of many researchers is precisely to devalue journalism by focusing on the ideological and professional dimension, a trend in criticism that disqualifies the very existence of a theory of journalism or even of studies that take the autonomy of this field into consideration. In our opinion this happens due to a number of reasons:

a) Journalism is not thought of as a theoretical place from which one can reflect on the journalistic phenomenon. 
b) Researchers use the theoretical references of other areas, changing their perspectives as needed, which does not take into consideration the rapid changes the subject might undergo.

c) Many existing theories of journalism - when used as references by these works - limit themselves to describing journalism and its professional and deontological practices, or select a certain genre as more central to understanding journalism, or totally disqualify journalism as a feasible area of knowledge.

d) The lack of studies applying a particular theoretical viewpoint that explicits a certain journalistic practice from the past and that derives from this explanation one possible way to enrich our understanding of journalism.

The findings of our research also enable a widening of working concepts for an understanding of the field, making the confrontation with existing approaches to a theory of journalism more productive: in the first place, due to its thematic variation, which reveals journalism 's complexities while requiring a broadening of the concept of journalism under scrutiny, and secondly, due to the proven relevance to our area of knowledge of research questions that take into consideration a theory of journalism or even a tentative construction of concepts and hypotheses that help map out the area. One notices too that establishing premises, suppositions, variables and hypotheses may not serve to discard investigation but more appropriately, to "open up questions" on the terms that Veyne (1974) proposes - that is, to ask the past questions and presuppositions that reveal new events and facts and that, because of explicitation, help to understand journalism. Concerning theory and its approach, it is possible to observe that certain combinations reduce journalism to aspects of its manifestations while others value it because it reveals the multiplicity of aspects that eventually evolve into concepts, themes and modes of appropriation.

Let us recall some of the hypotheses of this research: the methodological path or strategy of a given author is defined by the very conception of journalism that he shares; the theoretical basis for research on the history of journalism is found in a third discipline that instills the necessary concept and methods; this happens precisely because history is prone to articulating itself with other disciplines and fields of knowledge and because of the scarcity of genuinely journalistic theories and concepts. In the theses from postgraduate communication programs, one notices that the theory of journalism occupies little space. Consequently, the dissemination of the usage and the theoretical contamination from 
other fields that are not history nor journalism become normal.

In the case of the research works scrutinized here, the majority of the theses make reference to concepts related to language sciences. Sociology contributes concepts to help analyze editorial staffs, the behavior of their professionals or their relation with the social stricture (special attention is given to political parties, unions, intellectuals etc.). Example concepts: "institution", "social action", "praxis". Politics is seen as auxiliary to many research works and in many ways: through the connections between journalism and the state, political militancy, political parties, ideologies, etc. In addition, practically every research that takes note of a contextual history of the subject studied mentions the governing political figure at the time, the reigning political situation and the interference of the government. In this light, another area of interest is economy, especially when it comes to industrialization programs, public policies, administrative situation of enterprises, patronage, public consumption potential, etc.

What becomes evident here is that working from concepts and hypotheses from other academic areas is not a problem in and by itself. Alliances with other disciplines enventually enrich works on the history of journalism. What becomes troublesome is the researcher's lack of will to establish concepts for journalism or even to try and think of journalism from the reference points proposed by the theories of journalism. We understand that only from this perspective it is possible to speak of a epistemological field in search of its bearings. Researchers in journalism normally go to other fields of knowledge but never come back and thus fail to contribute conceptually to journalism. In such cases, we are not dealing with interdisciplinary but with "extradisciplinary" research.

It is possible to observe, therefore, from the theoreticalmethodological path of the majority of the theses that the relationship between journalism and history is complemented by the theorical references and methodological procedures that come from other areas of knowledge. The questions asked by the research many times do not regard journalism as a subject for study but rather limit researchers to conceptualizing journalism only from its empirical subjects. Some researchers go as far as taking newspaper and major editorial enterprises as their sole parameter for conceptualizing journalism. What becomes evident is that this manner of conceptualizing journalism takes it away from the hypothesis. This happens for instance when the researcher is believed to refute journalism when he criticizes a certain newpaper, an aspect of the reigning professional ideology or even concepts such 
as objectivity and neutrality (concepts used when referring to the daily news). Another way of hindering an understanding of journalism involves the research works that deal with narrative and discursive analysis merely to criticize journalism but hardly taking notice that journalism constructs itself as narrative. In these works the researcher spends some time discussing and describing semiotic theory, and eventually comes to the conclusion that journalism is not exactly objective and therefore needs to be understood as narrative. If taking this flaw (of not regarding journalism as narrative) into account is important, then the theoretical momentum involves pointing out the peculiarities of journalism as narrative.

Yet another aspect to be considered is that journalism gathers strength as a subject of analysis in journalism history when the empirical subject brings complexity to the very concept of journalism. What becomes evident is that because of the lack of theoretical reference or conceptualizing research, the concept of journalism relies too much on empirical subjects. The changes that take place at editorial offices, the concepts used by journalism, the changes caused by new technologies, the political context and the recognition of its relation to journalistic enterprises in any given period end up generating concepts of journalism. The result is that some research takes empirical reality as a valid concept to be applied throughout journalism. This conceptualizing becomes exhausted as that particular political, technological, empirical subject changes or evolves in time.

As one last observation, we reaffirm that the relationship between history, journalism and any other discipline, in the best interest of journalism, is strategic to epistemological research because the ways in which journalism actively participates in this relationship are a direct consequence of how and what concepts get constructed on and about journalism. History only helps define the journalistic field when the researcher makes an epistemological effort in his research. Methodological choices, the ways we view our subject, how we formulate our questions and hypotheses are intrinsic to the way journalism is regarded throughout these research works.

In the light of the aspects considered here, the history of journalism becomes crucial to journalistic theory. It serves to authenticate that journalism cannot merely rely on its present practices. It serves to reiterate that given the multiplicity of journalistic manifestations, one must not restrict the concept to a part of journalism. It also affirms that one's research must not abstain from conceptualizing, explaining and illuminating theoretical and practical aspects that are not yet 
understood. The history of journalism has the necessary strength and scope to contribute to the construction of the foundations for a theory of journalism if research in the area could go beyond revitalizing the memory of journalistic personalities, retrieving the history of the press and the biographies of its founders or treating journalism as documents for further investigation by other areas of knowledge. At the crossroads of journalism and history one can sense a strengthening of the journalistic field, one which sheds new light on both traditional and emerging questions related to the pratice and the theory of journalism.

\section{| NOTES}

1 This text is the result of a research work conducted with funding from the National Council for Scientific Development (CNPq) on "Theoretical and methodological strategies in research in journalism" (Edital CNPq 003/2008). A more detailed analysis can be found on Felipe Simão Pontes' dissertation "Theory and History of Journalism" at POSJOR/UFSC under the supervision of Ph.D. Professor Gislene Silva.

2 The 20 postgraduate programs with theses and/or dissertations until 2006 are: Universidade Federal do Rio Grande do Sul (UFRCS), Universidade do Vale do Rio dos Sinos (Unisinos), Pontifícia Universidade Católica do Rio Grande do Sul (PUC-RS), Universidade Tuiuti do Paraná (UTP), Universidade de Brasília (UnB), Universidade Federal da Bahia (UFBA), Universidade Federal de Pernambuco (UFPE), Universidade Federal de Minas Gerais (UFMG), Universidade de São Paulo (USP), Pontifícia Universidade Católica de São Paulo (PUC-SP), Universidade Metodista de São Paulo (UMESP), Universidade Estadual de São Paulo (UNESP), Universidade Estadual de Campinas (Unicamp), Faculdade de Comunicação Social Casper Líbero (FCSCL), Universidade de Marília (Unimar), Universidade Paulista (UNIP), Pontifícia Universidade Católica do Rio de Janeiro (PUC-RJ), Universidade Estadual do Rio de Janeiro (UERJ), Universidade Federal Fluminense (UFF) and Universidade Federal do Rio de Janeiro (UFRJ).

3 There are references indicating the number of theses and dissertations in communication at PUC-SP, however, data regarding title, author, year of publication and/or abstract could not be retrieved. The number here refer to the amount of theses in journalism and in the history of journalism that are available in Capes databases from 1987 through 2006 and in research conducted by Stumpf and Capparelli and Stumpf, Rocha and Vanz from 1992 to 2002. 
4 The number of dissertations from PUC-SP refers to the years 1992 to 2002. We have opted not to complete the research at the institution because of the extensive selection and time-consuming process, deciding to study only the theses. Thus the total number of dissertations is not conclusive.

\section{| BIBLIOGRAPHY}

BARBOSA, Marialva; RIBEIRO, Ana Paula G. O que a história pode legar aos estudos em jornalismo? Contracampo: revista do Mestrado em Comunicação, Imagem e Informação. Niterói: Universidade Federal Fluminense, v.12, p.51-61, 1st semester 2005 .

BERGER, Christa. (2001). A pesquisa em comunicação na América Latina. Hohlfeldt, A., Martino, L.C. e França, V. V. (orgs). In: Teorias da comunicação: conceitos, escolas e tendências. Petrópolis, RJ: Vozes.

BRAGA, José Luiz. "Lugar de Fala" como Conceito Metodológico no Estudo de Produtos Culturais. Text presented at the V Annual Meeting of Compós. São Paulo: ECA/USP, 1996

_. Constituição do Campo da Comunicação. In: FAUSTO NETO, Antônio; PRADO, José A.; PORTO, Sergio D. Campo da comunicação. João Pessoa: Editora Universitária, 2001.

DUARTE, Jorge e Antonio Barros (2006). Métodos e técnicas de pesquisa em comunicação. São Paulo: Atlas, 2006.

FOUCAULT, Michel (1966). As Palavras e as coisas: uma arqueologia das ciências humanas. $8^{\mathrm{a}}$ Ed. São Paulo: Martins Fontes, 2002

GARDINER, Patrick (1959). Teorias da História. Lisbon: Fundação Calouste Gulbenkian, 1984.

GENRO FILHO, Adelmo. Segredo da pirâmide: Para uma teoria marxista do jornalismo. Florianópolis: Masters Dissertation of the Postgraduate Program in Political Socialogy at UFSC, 1987.

HOHLFELDT, Antonio e Aline Strelow (2007). Metodologias de pesquisa: o estado da arte no campo do jornalismo - Intercom Study Nucleus, V National Meeting of Journalism Researchers - SBPJor, Aracaju, Sergipe, 2007.

LAGO, Cláudia e BENETTI, Márcia (orgs). Metodologia de pesquisa em jornalismo. Petrópolis: Vozes, 2007.

LE GOFF, Jacques; NORA, Pierre (1974). História: novos problemas. Rio de Janeiro: F. Alves, 1988.

LOPES, Maria I. V. (org) (2003). Epistemologia da Comunicação. São Paulo: Editora Loyola, 2003.

Sobre o Estatuto Disciplinar do campo da Comunicação. In: Epistemologia da Comunicação. São Paulo: Editora Loyola, 2003. 
THEORETICAL AND METHODOLOGICAL JOURNEYS IN THE HISTORY OF JOURNALISM IN THESES...

MALDONADO, Alberto E (2003). Explorações sobre a Problemática Epistemológica no Campo das Ciências da Comunicação. In: LOPES, Maria I. V. (org). Epistemologia da Comunicação. São Paulo: Editora Loyola, 2003 p. 205-225.

MELO, José Marques de (2007). Pensamento jornalístico: a moderna tradição brasileira. São Paulo: Intercom - Revista Brasileira de Ciências da Comunicação, v. 30, n. 02, July/Dec 2007, p. 15-40.

PORTO, Sergio D. (org.) Cadernos do Departamento de Comunicação da UnB. Terceiro número. Brasília: Mestrado em Comunicação da UnB, 1982.

RICOUER, Paul (1983). Tempo e narrativa -tomo 1. Campinas (SP):Papirus Ed, 1994.

ROMANCINI, Richard (2007). História e Jornalismo: reflexões sobre campos de pesquisas. In: LAGO, Cláudia; MACHADO, Márcia Benetti (org). Metodologia de pesquisa em jornalismo. Petrópolis RJ: Editora Vozes, 2007, p. 23-47.

SANTAELA, Lúcia. Comunicação e Pesquisa. São Paulo: Hacker, 1999.

SILVA, Gislene. Do detalhe ao talhe: dissertações-teses em Comunicação Rural - uma revisão. Dissertação apresentada no Programa de Comunicação da Universidade Metodista de São Paulo, São Bernardo do Campo, 1989.

SILVA, Gislene e PONTES, Felipe S. Teorias da notícia: impasses para a teoria do jornalismo. São Bernardo do Campo (SP): VI Meeting of SBPJor, 2008.

SILVA, Mário Camarinha; Cavalcanti, Ilce G. Catálogo das Teses e Dissertações. Rio de Janeiro: Biblioteca da Escola de Comunicação da Universidade Federal do Rio de Janeiro (ECO-UFRJ), 1989.

SOUSA, Jorge Pedro (2004). Elementos de teoria e pesquisa da comunicação e da mídia. Florianópolis, SC: Letras Contemporâneas, 2004.

STUMPF, Ida; CAPPARELLI, Sérgio (org). Teses e dissertações em Comunicação no Brasil: Resumos 1992-1996. Porto Alegre: PPGCom/ UFRGS, s/d. Available at www.ppgcom.ufrgs.br.

.Teses e Dissertações em Comunicação no Brasil: Resumos 19971999. Porto Alegre: PPGCom/ UFRGS, 2001.

STUMPF, Ida; ROCHA, Rafael; VANZ, Samile. Teses e dissertações em Comunicação no Brasil: Resumos 2000-2002. Porto Alegre: PPGCom/ UFRGS, s/d. Available at www.ppgcom.ufrgs.br.

Informação e conhecimento no jornalismo. In: Revista Estudos em Jornalismo e Mídia. Vol 2, n0 2. Florianópolis: Insular, 2005.

VEYNE, Paul (1971). Como se escreve a História. Brasília: Editora da Universidade de Brasília, 1982.

. (1974) A história conceitual. In: LE GOFF, Jacques; NORA, Pierre. 
História: novos problemas. Rio de Janeiro: F. Alves, 1988, p. 65-88.

WILKERSON, Marcus M. History and Journalism Research. In: NAFIZIGER, Ralph O; WILKERSON, Marcus M. An introduction to Journalism Research. New York: Greenwood Press Publishers, 1968, p. 09-25.

ZELIZER. Barbie. Taking journalism seriously: News and the academy. London: Sage, 2004.

Felipe Simão Pontes is a Provisional Professor of Journalism, UFSC Federal University of Santa Catarina MA in Journalism, UFSC.

E-mail: felipe271184@yahoo.com.br

Gislene Silva is a Full Professor of Journalism, UFSC - Federal University of Santa Catarina, coordinator of the Postgraduate Program in Journalism. E-mail: gislenedasilva@gmail.com 